Available online at GSC Online Press Directory

GSC Biological and Pharmaceutical Sciences

e-ISSN: 2581-3250, CODEN (USA): GBPSC2

Journal homepage: https://www.gsconlinepress.com/journals/gscbps

(RESEARCH ARTICLE)

\title{
Functional and molecular characterization of plant growth promoting bacteria associated with sugarcane cultivated in Tay Ninh Province, Vietnam
}

\author{
Hoang Minh Tam ${ }^{1,}{ }^{*}$, Dang Thi Ngoc Thanh ${ }^{1}$ and Cao Ngoc Diệp ${ }^{2}$ \\ ${ }^{1}$ Department of Natural Science Teacher Training, Sai Gon University, HCM City, Vietnam. \\ ${ }^{2}$ Dept. Microbiology Biotechnology, Biotechnology R\&D Institute, Can Tho University, Can Tho City, Vietnam.
}

Publication history: Received on 09 May 2020; revised on 21 May 2020; accepted on 24 May 2020

Article DOI: https://doi.org/10.30574/gscbps.2020.11.2.0136

\begin{abstract}
Bacteria associated with sugarcane were investigated characteristics of plant growth promotion and identified base on molecular characteristics. Nitrogen fixation bacteria were isolated by using N-free Burk's and LGI media. Pure colonies were then streaked on NBRIP medium to select phosphate solubilizing bacteria. The ability of producing IAA was screened by dropping Salkowski reagent into the bacterial suspension. There were 140 isolates of nitrogen-fixing and phosphate-solubilizing bacteria, and 41 isolates among them showed IAA producing. The abilities of producing IAA, fixing nitrogen, and solubilizing phosphate of these 41 isolates ranged from 1.9 to $12.8 \mathrm{mg} \mathrm{L}^{-1} \mathrm{IAA}, 0.1$ to $2.5 \mathrm{mg} \mathrm{L}^{-1} \mathrm{NH}_{4}^{+}$, and 32.4 - $286.5 \mathrm{mg} \mathrm{L}^{-1} \mathrm{P}_{2} \mathrm{O}_{5}$, respectively. Thirteen selected isolates were preliminary tested biological control ability and identified base on $16 \mathrm{~S}$ rDNA sequencing. There were 4 isolates capable of producing siderophore, 8 isolates inhibit Fusarium sp., 4 isolates inhibit Aspergillus niger, and one isolate capable of resisting both Escherichia coli and Staphylococcus aureus. The identification result showed these isolates belong to genera Stenotrophomonas, Bacillus, Chitinophaga, Burkholderia, Serratia, and Acinetobacter. These outstanding isolates were proposed to test the ability to promote sugarcane growth.
\end{abstract}

Keywords: Plant associated bacteria; Plant growth promoting bacteria; Biological control; Nitrogen fixation; Sugarcane.

\section{Introduction}

Sugarcane is an important industrial crop that to meet sugar consumption demand as well as material source for ethanol production. Sugarcane cultivation on an industrial scale has caused environmental problems including energy consumption of production systems, increasing greenhouse gas emissions, changes in physical, chemical and biological properties of soil. Monoculture of sugarcane with a large area, using a lot of chemical fertilizers and plant protection chemicals also causes soil pollution and degradation of surface water and air quality [1].

For the chemical fertilizers, NPK fertilizer use efficiency is generally low due to capable of using fertilizers of the plants and fertilizers properties such as leaching of $\mathrm{N}$ fertilizer, immobilization of $\mathrm{P}$ inorganic, evaporation to the atmosphere [2], [3]. To overcome this situation, in advanced countries, the amount of fertilizer has been commonly proposed based on analyzing nutrients present in soil and plants. The recommended amount of NPK applying for sugarcane cultivated

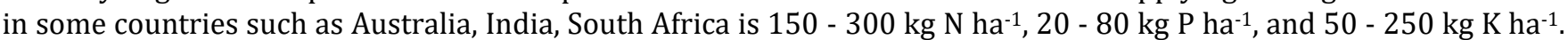
Meanwhile, in some South American countries such as Brazil and Columbia, fertilizer is often lower, especially nitrogen fertilizer ranging from $40-100 \mathrm{~N} \mathrm{ha}^{-1}$ [3]. According to Döbereiner, the low fertilizer demand may be due to biological fixation of bacteria associated with rhizosphere of sugarcane [4]. The reduction of nitrogen fertilizer to $60 \mathrm{~kg} \mathrm{~N}$ ha-1 facilitated the biological nitrogen fixation (BNF) of bacteria such as Glucanacetobacter diazotrophicus [5]. These bacteria were also isolated from sugarcane grown in Australia with low N- applying levels while there was no evidence of BNF

\footnotetext{
* Corresponding author: Hoang Minh Tam
} 
in regions with high $\mathrm{N}$-applying in Brazil [6]. Researchers in Brazil are also trying to reduce the applying of nitrogen fertilizer by a half (about 125,000 tons of $\mathrm{N}$ fertilizer, equivalent to 62.5 million USD every year), the rest would take advantage of the supply from BNF. This approach not only helps significantly reduce the cost of producing sugar cane and bioenergy worldwide but also brings benefits to the soil and the environment [7]. Not only Glucanacetobacter diazotrophicus but more than other 80 species of PGPB associated with sugarcane have been also reported, eg. Acinetobacter baumanii, Bacillus subtilis, Burkholderia vietnamiensis, Serratia spp., Stenotrophomonas maltophilia [7]. The capable of plant growth promoting may be achieved by direct mechanisms such as nitrogen-fixing, phosphatesolubilizing, phytohormones-producing of the bacteria [2], [8]. The applications of Plant Growth Promoting Rhizobacteria (PGPR) in sustainable environmental management due to their ability in biological control, biodegradation, environmental stress control, climate change prevention, and enhancement of soil fertility were also mentioned [8].

In Vietnam, sugarcane cultivation for sugar production began in the 1990s. Due to its adaptation to natural conditions, sugarcane can be grown in many places throughout the country, in which, Tay Ninh is the province with the largest sugarcane planting area of the Southeast. In 2017, the sugarcane planting area of this province was 15.6 thousand hectares, accounting for about $5.6 \%$ of the area of the country. However, the major agricultural soil of Tay Ninh is gray soil (acrisols), accounting for more than $85.6 \%$ of the natural area [9]. NPK fertilizer applied to sugarcane grown on

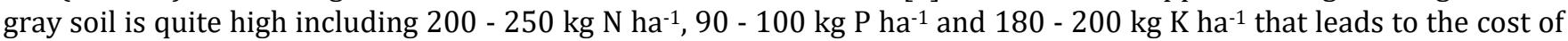
finished sugar product is high and the low competitiveness [10]. Meanwhile, many species of sugarcane-associated bacteria have also been isolated, identified and characterized functional properties such as BNF, phosphate solubilization, IAA production [11]-[15]. Effects of Pseudomonas spp. and Gluconacetobacter diazotrophicus on sugarcane yield and sugar concentration were also evaluated [16], [17]. These data show that the isolation and identification of bacteria associated with sugarcane grown in Tay Ninh has a basis and is necessary for development of sustainable and environmentally friendly sugarcane cultivation in this locality. The concept of "functional characterization" and "molecular characterization" is based on the literature of [18], and the research limits are screening PGP straits of bacteria at the test tube scale and the identification based on 16S rDNA sequencing.

\section{Material and methods}

\subsection{Samples collection}

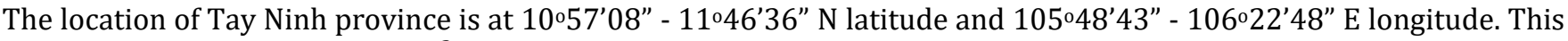
province has an area of $4,028 \mathrm{~km}^{2}$, and subdivided into 8 districts and one provincial city. Except for Tay Ninh city and Hoa Thanh district which had small sugarcane areas, the remaining 6 districts had been sampled at 24 sugarcane fields (Figure 1) with 5 plants per field. The aerial parts that $30 \mathrm{~cm}$ above the ground of each sugarcane plant (6-months old) had been cut off. The rest of the stem and roots and the soil surrounding the roots were collected, packed, labeled and transported to the laboratory [13], [14]. At the laboratory, the collection of rhizospheric soil samples was carried out according to the shaking method, ID:13_Turpault [19]. Soil samples had been dried at approximately $40^{\circ} \mathrm{C}$ to constant mass (air-dry soil). The rhizospheric soil that collected from 5 plant-samples in a sugarcane field was mixed to form a composite sample.

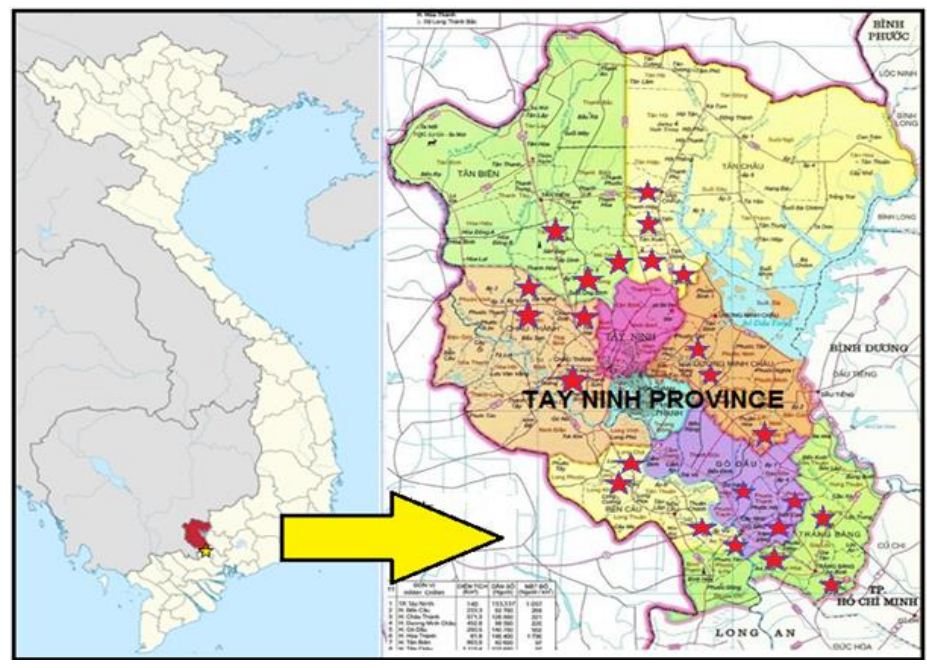

Figure 1 The map of Tay Ninh province and 24 places of sampling. 
The star shapes used to illustrate the wards of the six districts that were sampled.

\subsection{Isolation and collection of bacteria have capable of fixing nitrogen and solubilizing phosphate}

\subsubsection{Isolation of rhizospheric bacteria capable of nitrogen-fixing}

One gram of rhizosphere soil was suspended in $99 \mathrm{~mL}$ sterile water, shaken at $200 \mathrm{rpm}$ for 10 minutes and deposited for 3 hours. After 3 hours, the supernatant was collected and streaked on N-free Burk's agar plates [20]. These plates were incubated at $28 \pm 2^{\circ} \mathrm{C}$ for $2-3$ days to observe and select bacterial colonies. Pure isolates were collected by streaking on Burk's medium repeatedly.

\subsubsection{Isolation of endophytic bacteria capable of nitrogen-fixing}

Plant tissue samples were sterilized and extracted according to the method of [13]. The extract was then inoculated onto the test tube containing semisolid N-free LGI medium to observe the appearance of the pellicle. The liquid that collected from the pellicle was continuously streaked on LGI agar plates to obtain single colonies [13]. Pure isolates were collected by streaking on LGI medium repeatedly.

\subsubsection{Collection of bacteria capable of nitrogen-fixing and solubilizing phosphate}

The nitrogen-fixing bacteria that collected from the experiments described above had been conducted screening the ability of solubilizing phosphate. Each pure isolate had been transferred to NBRIP media agar plates [21]. Any isolates that grew on the medium containing insoluble calcium orthophosphate were the isolate capable of dissolving phosphate.

\subsection{Morphological characterization of bacterial isolates}

Colony morphology including form, elevation, margin, surface and size were recorded after 48-72 hours of growth on isolation media. Cellular size and shape of bacteria were observed by light microscopy. Gram stain and KOH String Test were performed according to instructions of [22] and [23].

\subsection{Plant-Growth-Promoting functional characterization}

\subsubsection{Detection and quantification of IAA production}

The bacterial isolates that had been cultured on Burk's agar plates within 4 days would had been visually detected their abilities of IAA production by dropping directly $100 \mu \mathrm{L}$ the Salkowski reagent on their colonies [24] and incubated in dark for $30 \mathrm{~min}$. The color change of sample to other color such as orange, pink, brownish indicates the presence of IAA.

For quantification, $1 \mathrm{~mL}$ of the pre-culture had been adjusted to the turbidity of a $0.5 \mathrm{McFarland}$ Standard $\left(1.5 \times 10^{\wedge} 8\right.$ $\mathrm{CFU} / \mathrm{mL}$ ) [25] was transferred to $50 \mathrm{~mL}$ of Burk's broth, then incubated continuously within 8 days at $120 \mathrm{rpm}$ (rounds per minute), $28 \pm 2^{\circ} \mathrm{C}$. Periodically, $10 \mathrm{~mL}$ suspension was collected at 2, 4, 6, 8 DAI (days after inoculation), then centrifuged at 12,000 rpm for 5 minutes to obtain the supernatant for colorimetric analysis. The quantification of IAA was conducted with Salkowski reagent. The ratio of sample and reagent was 4:1 (v/v) [24]. After 15 minutes of incubated in dark, OD (Optical Density) of the sample was measured by spectrophotometer at a wavelength of $530 \mathrm{~nm}$.

\subsubsection{Quantification of nitrogen fixation and phosphate solubilization}

This experiment was limited to the isolates that capable producing IAA. The preparation of suspension was similarly to the above description but the Burk's broth used for nitrogen fixation testing and NBRIP broth used for phosphate solubilization testing. A volume of $10 \mathrm{~mL}$ of suspensions had been periodically collected at 2, 4, 6, 8 DAI for ammonia test, and at 5, 10,15, 20 DAI for soluble phosphate test. Then the suspension was centrifuged at 12,000 rpm for 5 minutes to obtain the supernatant that used for the next colorimetric analysis.

The quantification of ammonia was conducted by using phenol-hypochlorite method [26]. The ratio of sample and reagent was $5: 1(\mathrm{v} / \mathrm{v})$. The $\mathrm{OD}$ was measured at $640 \mathrm{~nm}$ after 30 minutes of the reaction stability. Similarly, quantitative survey of phosphate-solubilizing was conducted by using phosphomolybdate colorimetric method [27]. The sample and reagent ratio was also $5: 1(\mathrm{v} / \mathrm{v})$. The $\mathrm{OD}$ was measured at $880 \mathrm{~nm}$ after 15 minutes of the reaction stability. 


\subsubsection{Preliminary survey of biological control ability of selected isolates}

This survey was limited in bacterial isolates that had the best quantitative results of nitrogen-fixation, phosphatesolubilization, and IAA production, and include three experiments: (1) detection of siderophore-producing, (2) detection of antibacterial activity, and (3) detection of antifungal activity.

\section{Detection of siderophore-producing}

The detection of siderophore was conducted by using liquid CAS assay. The CAS solution was prepared according to the recipe of Schwyn and Neilands [28]. The colony of each selected isolate was inoculated into $5 \mathrm{~mL}$ the Peptone Sucrose Broth (PSB) [29] and incubated at $28 \pm 2^{\circ} \mathrm{C}, 120 \mathrm{rpm}$ for 48 hours. One $\mathrm{mL}$ of supernatant was centrifuged at $12,000 \mathrm{rpm}$ for 5 minutes. The supernatant was obtained and transferred to a fresh tube, then mixed with an equal volume of CAS. The mixture was incubated in the dark for 30 minutes and then observed the color change. The color change of blue CAS reagent to another color such as orange, purple, green indicates the presence of siderophore [30], [31]. The bacterial isolates which changed the color of the CAS solution were further investigated of creating halo zone on CAS agar plate by using paper-disc agar diffusion assay. The diameter of disc-paper was $5 \mathrm{~mm}$ [32].

\section{Detection of antibacterial activity}

The agar well diffusion method [33] was used to evaluate the antimicrobial activity of selected isolates. Two strains of indicator bacteria including Escherichia coli and Staphylococcus aureus had been growth individually in PS Broth for 48 hours and then adjusted cell density to McFarland Standard 0.5. One $\mathrm{mL}$ of pre-culture suspension of the indicator was inoculated into a test tube containing $10 \mathrm{~mL}$ of sterilized PSA medium with $0.3 \%$ agar (w/w) and cool down to $55^{\circ} \mathrm{C}$, mixed well and poured on surface of a plate containing PSA medium $(1.8 \%$ agar w/w) [34].

Six to nine holes with a diameter of $5 \mathrm{~mm}$ is aseptically punched. A volume of $50 \mu \mathrm{L}$ of suspension of each selected isolates at a concentration of $1.5 \times 10^{\wedge} 8 \mathrm{CFU} / \mathrm{mL}$ that had been pre-cultured in PS Broth was introduced into the well. These experimental plates were incubated at $28 \pm 20 \mathrm{C}$ for 48 hours to observe the appearance of inhibition zones.

\section{Detection of antifungal activity}

Similarly, the agar well diffusion method was also used to evaluate the antifungal activity of selected isolates. Two strains of indicator fungi including Fusarium sp. and Aspergillus niger had been growth individually in Potato Dextrose Agar (PDA) medium for 5 days at $28 \pm 2^{\circ} \mathrm{C}$ to obtain fungal discs [35]. Each fungal disc was made by using a sterile glass tube to drilling and lifting up a colony, and then was transferred into the experimental plate that with the wells filled with $50 \mu \mathrm{L}$ of bacterial suspension as had described above. These experimental plates were incubated at $28 \pm 2^{\circ} \mathrm{C}$ for 2 5 days to observe the appearance of inhibition zones.

\section{Molecular characterization}

This survey was limited in bacterial isolates that had the best results in assays of Plant-Growth-Promoting function in vitro.

DNA of selected bacteria was isolated following the protocol of [13]. PCR procedures to amplify the 16S rDNA were conducted according to the description of [13], [14] with the primers p515FPL and p13B used for endophytic bacteria and the primers $27 \mathrm{~F}$ and 1492R used for rhizospheric bacteria. The 16S rDNA molecular of rhizospheric bacteria were also amplified by using the primers p515FPL and p13 for determining abilities of endophytic living. An aliquot of $10 \mu \mathrm{L}$ of each PCR product had been separated and visualized in 1\% agarose gels by using standard electrophoresis procedure. Sequencing partial16S rRNA genes of selected bacterial isolates had been conducted by MACROGEN Company, Korea.

The results of sequencing had been compared to reference sequence of 16S rRNA gene present in the GenBank of The National Center for Biotechnology Information (NCBI) (https://www.ncbi.nlm.nih.gov/) by using Nucleotide BLAST tool. The query sequences and reference sequences were used to infer the phylogenetic tree by using the NeighborJoining method with the bootstrap 1000. The software that had been used for this analysis was MEGA X (Molecular Evolutionary Genetics Analysis) (https://www.megasoftware.net/) [36].

\section{Experimental design and Data analyses}

Quantitative experiments were random assignment (Completely Randomized Design) with three replicates. Negative controls were conducted similarly to treatments, did not use bacterial suspension but put on sterilized corresponding medium instead. 
Statistics methods were ANOVA (Analysis of Variance) one factor and Duncan test at $\alpha=0.05$ by using IBM SPSS Statistics 20.0 .

\section{Results and discussion}

\subsection{Bacterial isolation}

There were 88 rhizospheric bacterial isolates and 106 endophytic bacterial isolates had been isolated from 72 samples of soil and plant tissues of sugarcane by using two types of N-free media as Burk's and LGI. After transferred to the NBRIP medium containing calcium orthophosphate as the only phosphorus source, there were 140 isolates of them including 62 rhizospheric isolates (accounted for 70.5\%) and 78 endophytic isolates (accounted for 73.6\%) that continued to grow thanks to the phosphate solubilization. On average, from a soil or plant tissue sample, there were 2.7 bacterial isolates capable of fixing nitrogen and 1.5 isolates capable of fixing nitrogen and solubilizing phosphate that had been isolated. The origin and the ability to growing on the specific media of these 140 isolates were described in Table 1.

Table 1 The origin and ability to growing on the media of the isolates

\begin{tabular}{|c|c|c|c|c|c|}
\hline \multicolumn{2}{|l|}{ Origin } & \multicolumn{3}{|c|}{ Number of isolates grew on types of media } & \multirow{2}{*}{$\begin{array}{l}\text { Total of isolates } \\
\text { of each district }\end{array}$} \\
\hline District & Type of Sample & Burk's & LGI & NBRIP & \\
\hline \multirow[t]{3}{*}{ Trang Bang } & Rhizospheric soil & 11 & & 9 & \multirow[t]{3}{*}{22} \\
\hline & Root & & 8 & 6 & \\
\hline & Stem & & 9 & 7 & \\
\hline \multirow[t]{3}{*}{ Tan Bien } & Rhizospheric soil & 13 & & 8 & \multirow[t]{3}{*}{18} \\
\hline & Root & & 8 & 5 & \\
\hline & Stem & & 7 & 5 & \\
\hline \multirow[t]{3}{*}{ Ben Cau } & Rhizospheric soil & 11 & & 8 & \multirow{3}{*}{23} \\
\hline & Root & & 13 & 11 & \\
\hline & Stem & & 6 & 4 & \\
\hline \multirow{3}{*}{$\begin{array}{l}\text { Duong Minh } \\
\text { Chau }\end{array}$} & Rhizospheric soil & 12 & & 7 & \multirow{3}{*}{16} \\
\hline & Root & & 6 & 5 & \\
\hline & Stem & & 6 & 4 & \\
\hline \multirow[t]{3}{*}{ Tan Chau } & Rhizospheric soil & 15 & & 10 & \multirow{3}{*}{19} \\
\hline & Root & & 7 & 4 & \\
\hline & Stem & & 6 & 5 & \\
\hline \multirow[t]{3}{*}{ Go Dau } & Rhizospheric soil & 10 & & 7 & \multirow{3}{*}{18} \\
\hline & Root & & 7 & 4 & \\
\hline & Stem & & 9 & 7 & \\
\hline \multirow[t]{3}{*}{ Chau Thanh } & Rhizospheric soil & 16 & & 13 & \multirow[t]{3}{*}{24} \\
\hline & Root & & 7 & 4 & \\
\hline & Stem & & 7 & 7 & \\
\hline \multicolumn{2}{|l|}{ Total } & 88 & 106 & 140 & 140 \\
\hline
\end{tabular}


Baldani et al. concluded a complete process to isolate free-living, associative and endophytic diazotrophic bacteria from sugarcane [37]. The appearance of the pellicle formed in a nitrogen-free semi-solid medium as LGI was a sign of diazotrophic bacterial growth (Figure 2A).

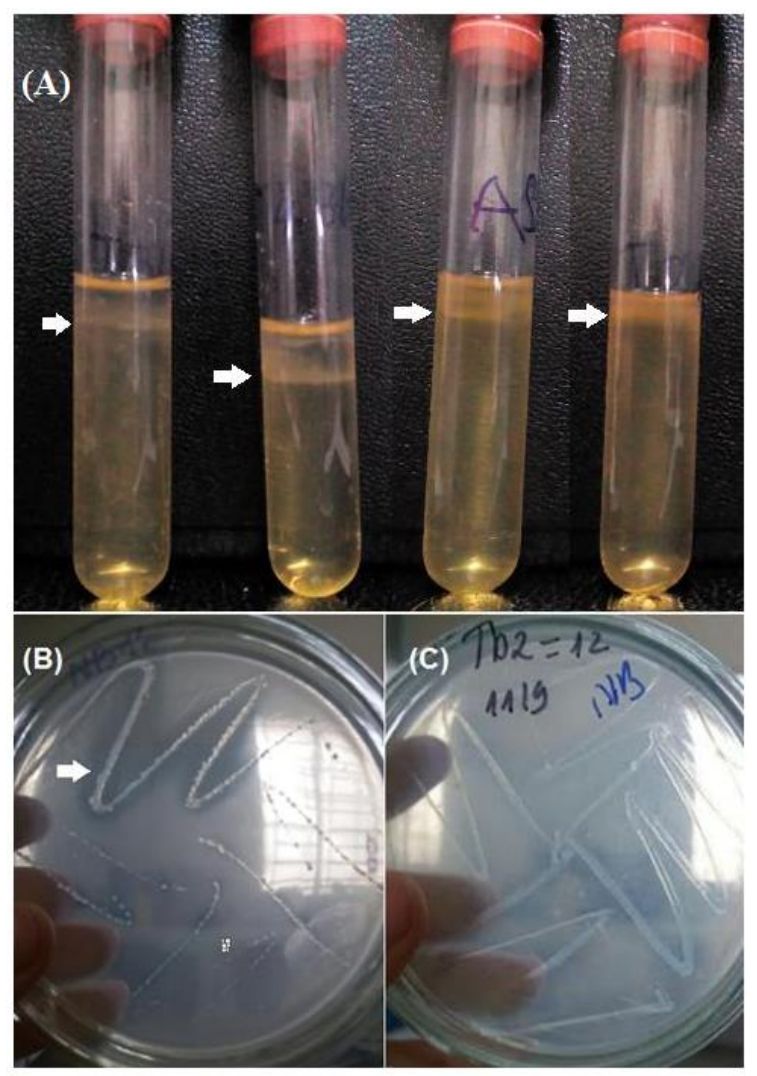

Figure 2 The appearance of the pellicle formed in N-free semisolid LGI (A).

Producing halo zone (B) or not (C) of bacteria while growing on solid NBRIP medium.

Similarly, Nautiyal also suggested some growth medium for screening phosphate solubilizing microorganisms in which NBRIP (National Botanical Research Institute's phosphate growth medium) was said to be more efficient than PVK (Pikovskaya medium). Although producing a halo on agar plates (Figure 2B) containing insoluble inorganic phosphate had been a criterion for phosphate solubilizer, it had been not an infallible technique. In the opposite, the direct measurement of phosphate solubilization in broth assay was said to be more reliable [21].

\subsection{Morphological characteristics of bacteria}

On isolation media, opaque white made up the majority, accounted for $48.7 \%$ of the total of rhizospheric bacterial isolates and $62.9 \%$ of the total of endophytic bacterial isolates. The ratio of translucent or transparent white was $5.1 \%$ and $16.1 \%$, yellow was $44.9 \%$ and $17.7 \%$, and other colors such as orange, beige were $1.3 \%$ and $3.2 \%$, respectively. The other morphological characteristics of colonies (not distinguish between rhizospheric and endophytic bacteria) included circular (84.3\%) and irregular (15.7\%), entire (50.7\%) and lobate (49.3\%), convex $(92.1 \%)$ and flat (7.9\%), and smooth $(100 \%)$. The majority of colonies have a diameter of $\leq 1 \mathrm{~mm}(63.6 \%)$. Colonies of $1-3 \mathrm{~mm}$ in diameter accounted for $36.4 \%$.

Through microscopic observation, there were $91.4 \%$ of the total bacterial isolates that exhibited their motility and $8.6 \%$ of them were non-motile. The bacilli bacteria accounted for $88.5 \%$, while the coccobacilli bacteria accounted for $11.4 \%$. Gram-negative bacteria accounted for $55.4 \%$, and Gram-positive bacteria accounted for $44.6 \%$. The records of morphological characteristics of each isolate were essential to support the subsequent identification. 


\subsection{PGP functional characteristics of bacteria}

\subsubsection{Ability to producing IAA, fixing nitrogen, and solubilizing phosphate}

The screening test of IAA production by dropping directly the Salkowski reagent into the bacterial suspension or on the colony showed that 41 isolates of the total 140 isolates (accounted for 29.3\%) had the ability. Dropping reagent on bacterial colony help to fast detect the isolates have the ability to produce IAA to put into quantitative experiment (Figure 3A). In the quantitative experiment of IAA of 41 isolates that were cultured in Burk's broth without tryptophan, the average value of the IAA content of 4 measure times that 2 days apart ranged from 1.9 to $12.8 \mathrm{mg} \mathrm{L}^{-1}$. The synthesis of IAA of plant associated bacteria under the condition of whether or not tryptophan has been summarized. The difference between IAA contents produced under conditions with or without tryptophan have also been reported [38].

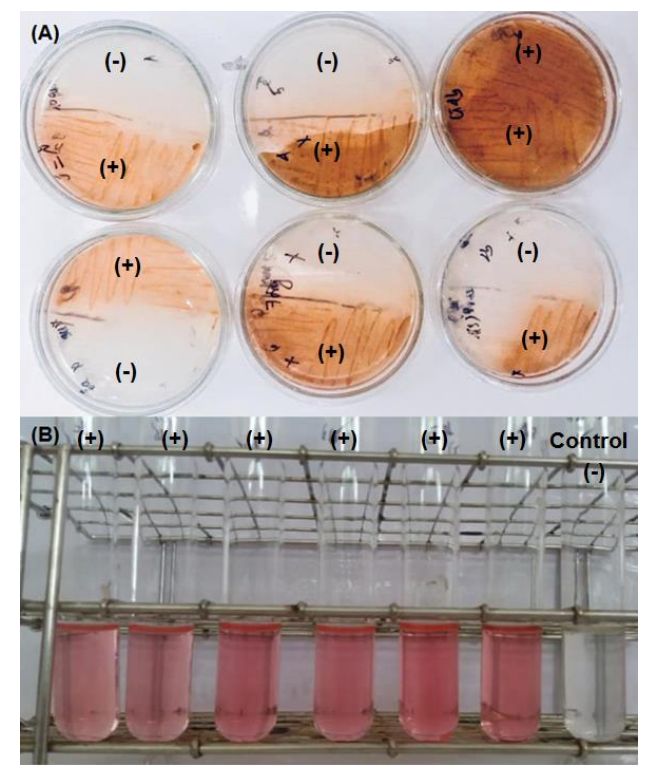

Figure 3 The change in color of culture medium in IAA detection (A) and quantification experiments (B) (-): negative result; (+): positive result

Table 2 In vitro Plant Growth Promoting functional characterization of 13 selected isolates

\begin{tabular}{|c|c|c|c|c|c|c|}
\hline \multirow{3}{*}{ Isolate } & \multicolumn{6}{|c|}{ In vitro Plant Growth Promoting Functional Characterization } \\
\hline & \multicolumn{2}{|c|}{$\begin{array}{l}\text { IAA-production } \\
\text { (mg IAA/L) }\end{array}$} & \multicolumn{2}{|c|}{$\begin{array}{l}\text { N-fixation } \\
\qquad\left(\mathrm{mg} \mathrm{NH}_{4}^{+} / \mathrm{L}\right)\end{array}$} & \multicolumn{2}{|c|}{$\begin{array}{l}\text { P-solubilization } \\
\left(\mathrm{mg} \mathrm{P}_{2} \mathrm{O}_{5} / \mathrm{L}\right)\end{array}$} \\
\hline & At 2 DAI & Average for 8 days & At 4 DAI & Average for 8 days & At $10 \mathrm{DAI}$ & Average for 20 days \\
\hline TBD2e & $0.8 \mathrm{pq}$ & 2.3 & $0.1^{\mathrm{n}}$ & 1.6 & $458.9^{b}$ & 228.2 \\
\hline TPD3b & $11.2^{\mathrm{d}}$ & 9.8 & $2.5 \mathrm{i}$ & 2.5 & $398.5^{c}$ & 265.1 \\
\hline BCD1a & $3.5 \mathrm{ij}$ & 5.7 & $2.8 \mathrm{gh}$ & 1.0 & $41.3 \mathrm{q}$ & 110.1 \\
\hline MCD1a & $8.1^{\mathrm{e}}$ & 4.2 & $4.4^{d}$ & 1.4 & $162.5^{l}$ & 67.4 \\
\hline $\mathrm{TCD} 2 \mathrm{~b}$ & $3.8^{\mathrm{ij}}$ & 6.6 & $1.4^{\mathrm{k}}$ & 0.9 & $610.4^{a}$ & 286.5 \\
\hline TBR3a & $13.4^{c}$ & 12.8 & $2.6^{i}$ & 1.0 & $308.8^{d}$ & 262.5 \\
\hline TPR4b & $2.2^{\mathrm{lm}}$ & 3.9 & $0.4^{n}$ & 0.4 & $142.4^{\mathrm{m}}$ & 117.2 \\
\hline BCR3a & $0.7 \mathrm{pq}$ & 2.9 & $0.3^{n}$ & 0.3 & $312.0^{\mathrm{d}}$ & 224.2 \\
\hline BCR5a & $5.0^{\mathrm{h}}$ & 6.6 & $5.0^{b}$ & 1.4 & $93.1^{\circ}$ & 141.4 \\
\hline MCR1a & $6.3 q$ & 1.9 & $5.0^{b}$ & 1.3 & $62.8^{p}$ & 114.2 \\
\hline TCT1a & $3.8^{\mathrm{ij}}$ & 4.8 & $0.1^{\mathrm{n}}$ & 0.3 & $113.6^{n}$ & 175.5 \\
\hline TCR1b & $7.1^{\mathrm{f}}$ & 5.8 & $0.4^{n}$ & 0.5 & $114.4^{\mathrm{n}}$ & 205.3 \\
\hline CT4bd & $11.3^{\mathrm{d}}$ & 9.3 & $6.8^{a}$ & 1.9 & $114.4^{n}$ & 205.3 \\
\hline
\end{tabular}


These 41 isolates were also examined the abilities to fixing nitrogen and solubilizing phosphate by colorimetric methods. The average value of the $\mathrm{NH}_{4}{ }^{+}$content of 4 times of measurement at 2-day distance in range from 0.1 to 2.5 $\mathrm{mg} \mathrm{L}^{-1}$ while the average values of dissolved phosphate contents of 4 times of measurement at 5-day distance were in range from 32.4 to $286.5 \mathrm{mg} \mathrm{P}_{2} \mathrm{O}_{5} \mathrm{~L}^{-1}$. Particularly, appropriate time for IAA production and nitrogen fixation of the majority of bacterial isolates was " 2 DAI" and "4 DAI" while "10 DAI" seemed to be the suitable time-point for phosphate solubilization similar to some authors' reports [39], [40]. Base on the results of quantitative surveys mentioned above, there were 13 isolates had expressed superiority in IAA production, nitrogen fixation, and phophate solubilization (Table 2).

\subsubsection{Ability to producing siderophore, inhibiting indicator fungi and bacteria}

The results of CAS solution and CAS agar plate assays showed only 4 isolates have the ability including TBD2e, TPD3b, TBR3a, TCR1b (Figure 4 A, B). Qualitative CAS assay have been used by many authors in many fields. The concentration of siderophore such as nigribactin, once increased, also causes the color of the post-reaction complex to change from blue to reddish purple or orange [41]. The ability to inhibit bacteria manifested only in one isolate was TPD3b with the halo diameter for $S$. aureus was $3.5 \mathrm{~mm}$, and for E. coli was $1 \mathrm{~mm}$ (Figure $4 \mathrm{C}$ ). Eight isolates including TBD2e, TPD3b, MCD1a, TCD2b, TBR3a, TPR4b, BCR5a, CT4bd were able to inhibit Fusarium sp., while only 4 isolates TBD2e, TPD3b, MCD1a, BCR5a were able to inhibit Aspergillus niger (Figure 4 D). The average diameter of the inhibition zone was $1 \mathrm{~cm}$ (Figure 4). Fusarium species such as Fusarium verticillioides, Fusarium proliferatum cause sugarcane diseases [42]. Fusarium oxysporum, Aspergillus niger were common phythopathogens. Many bacteria associated with sugarcane that were capable of resisting to Fusarium had been reported. PGPR such as Bacillus, Pseudomonas inhibit Fusarium and Aspergillus had been also isolate from many other plants [43]-[45].

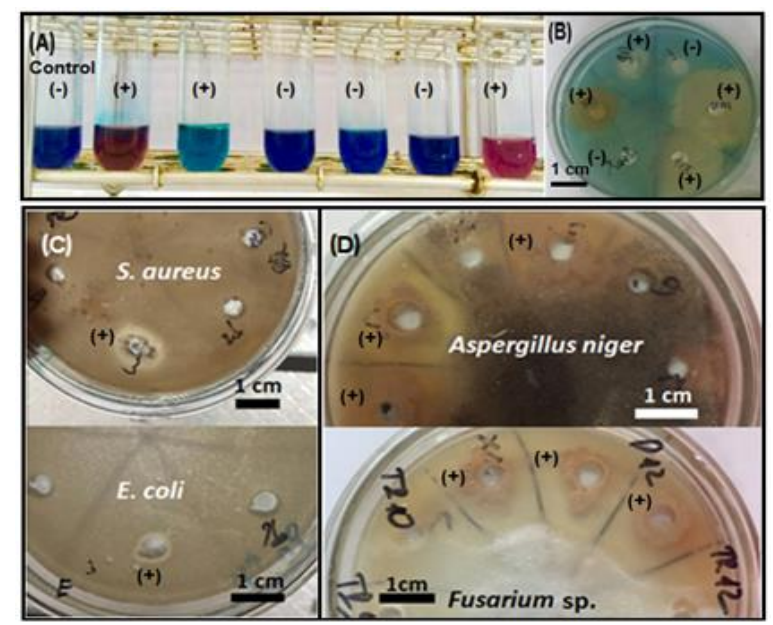

Figure 4 The results of siderophore test in CAS solution (A) and CAS agar plate (B); antibacterial (C) and antifungal (D) activity potential of some isolates.

\subsection{Identification results of selected isolates}

Base on the result of the PGP functional characteristics survey mentioned above, there were 5 rhizospheric bacterial isolates and 8 endophytic bacterial isolates that had been selected to identify. Similar to the report of Thanh and Tram, the morphology of bacterial colonies on the isolation media as LGI and Burk's was difficult to distinguish [40]. Thus, these 13 isolates have been streaked on the LB medium to record the morphology of colony and cell. It showed the suitability between species name and some morphological characteristics including shape of colony and cell, Gram staining (Figure 5), and motility. 

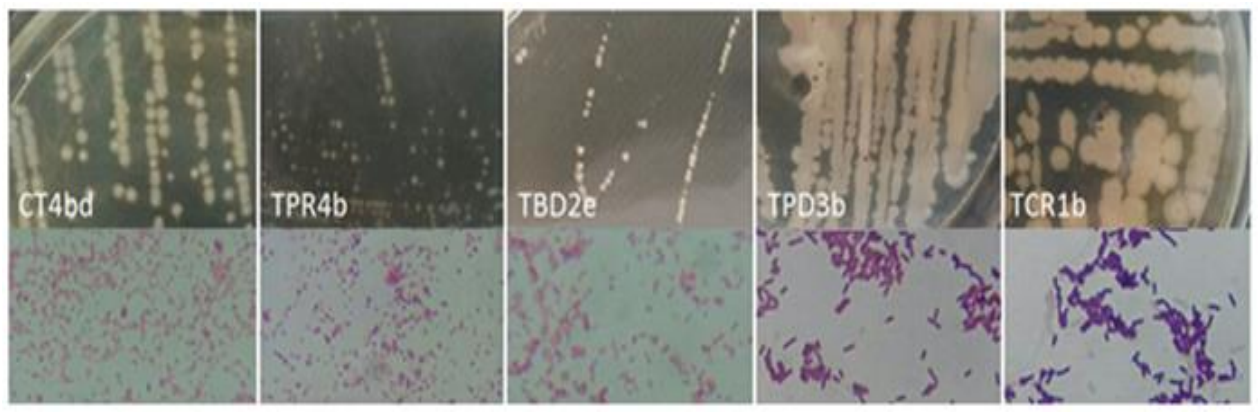

Figure 5 Colony morphology and Gram staining results of some isolates

Electrophoresis results of PCR products of 5 soil bacteria strains and 8 endogenous bacteria strains were present at $1500 \mathrm{bp}$ and $900 \mathrm{bp}$ respectively as reported by [13], [14]. The sequences of 16S rDNA gene of selected isolates in this study and the reference sequences from the GenBank were used to infer the phylogenetic trees (Figure 6 and Figure 7). The evolutionary distances shown in the scale bar and the bootstrap percentages were shown at the nodes of the tree.

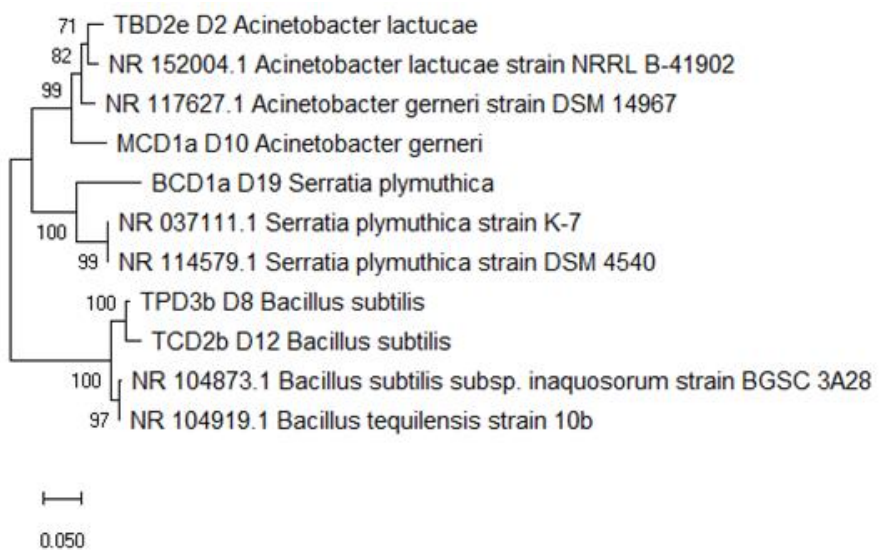

Figure 6 The phylogenetic tree showed the relative positions of 5 rhizospheric bacterial isolates with reference strains in the GenBank

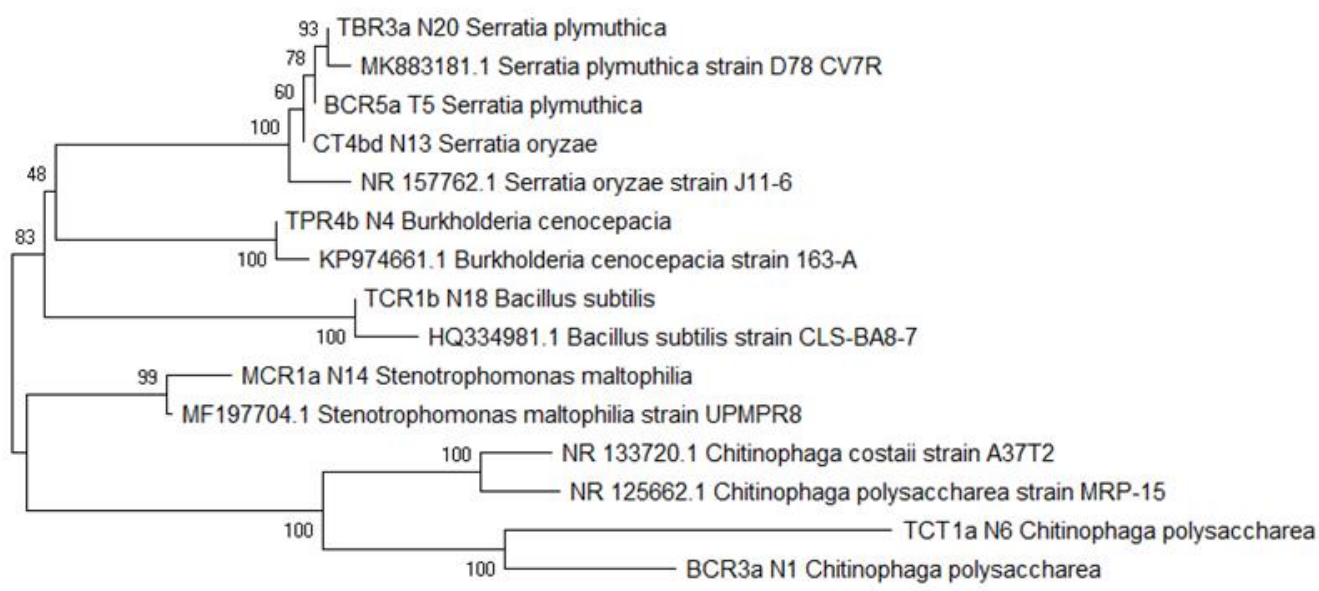

0.050

Figure 7 The phylogenetic tree showed the relative positions of 8 endophytic bacterial isolates with reference strains in the GenBank.

Through the results of molecular characterization, the identification of selected isolates was confirmed as follows: TBD2e was Acinetobacter lactucae; MCD1a was Acinetobacter gerneri; BCD1a, TBR3a, BCR5a were the same Serratia 
plymuthica; CT4bd was Serratia oryzae; TPR4b was Burkholderia cenocepacia; TCT1a, BCR3a were the same Chitinophaga polysaccharea; MCR1a was Stenotrophomonas maltophilia. All 10 isolates have been identified as Gram negative. The other three isolates include TPD3b, TCD2b, and TCR1b, which were the Gram-positive bacteria Bacillus subtilis.

Acinetobacter lactucae sp. nov. (NR152004) was a new species isolated from iceberg lettuce (Lactuca sativa) planted in USA [46], and Serratia oryzae sp. nov. (NR157762) was a new species isolated from stems of rice planted in China [47]. Chitinophaga polysaccharea strain MRP-15 was a new species isolated from the rhizoplane of Dioscorea japonica. Burkholderia cenocepacia (KP974661) was a diazotrophic bacteria associated to sugarcane varieties from Northeast Region of Brazil. While Stenotrophomonas maltophilia (MF197704) was a strain had the biological control activity against blast disease in Malaysia, and Bacillus subtilis (HQ334981) was a bacterial strain had the antimicrobial activity isolated from soil samples in Ladakh, India (These data were unpublished, query information received from NCBI at https://www.ncbi.nlm.nih.gov/). Bacillus subtilis had been isolated from the rhizosphere of sugarcane planted in India and showed the effectiveness of protecting sugarcane from salinity stress under greenhouse conditions [48]. Benefits of Bacillus include Bacillus subtilis in agriculture such as fertilizers, biocontrol and biotic stress-resistant inoculants have mentioned [49], [50].

\section{Conclusion}

Through the isolation and characterization of plant growth promoting function, 41 isolates with the ability of nitrogen fixation, phosphate solubilization, and IAA production were detected. There were 13 isolates in which had some additional capabilities related to biological antagonism such as siderophore production, antibacterial and antifungal activity. Molecular characterization based on the 16S rRNA gene showed that these isolates were benefit bacteria have been reported. All of these have opened up the prospect of using the selected bacterial isolates in this study in agriculture and the sugarcane production.

\section{Compliance with ethical standards}

\section{Acknowledgments}

The authors wish to thank the sponsorship of Saigon University, the support of research facilities of Ho Chi Minh City University of Science.

\section{Disclosure of conflict of interest}

There is no conflict of interest.

\section{References}

[1] Hartemink AE. (2008). Chapter 3 Sugarcane for Bioethanol: Soil and Environmental Issues, in Advances in Agronomy. Academic Press, 99, 125-182.

[2] Duarah I, Deka M, Saikia N and Boruah HPD. (2011). Phosphate solubilizers enhance NPK fertilizer use efficiency in rice and legume cultivation. Biotech, 1(4), 227-238.

[3] IPI Bulletin No. 21: Fertilizing for High Yield and Quality - Sugarcane.

[4] Döbereiner J. (1992). Recent changes in concepts of plant bacteria interactions: endophytic $\mathrm{N}_{2}$ fixing bacteria. Ciência e Cultura, 44(5), 310-313.

[5] Wood AW, Schroeder B and Dwyer R. (2010). Opportunities for improving the efficency of use of nitrogen fertiliser in the Australian sugar industry. 32nd Annual Conference of the Australian Society of Sugar Cane Technologist, 221-233.

[6] Chapman LS, Halsall DM and Gibson AH. (1992). Biological nitrogenfixation and sugarcane. In Proceedings of Australian Society of Sugarcane Technologists, 14, 90-93.

[7] Mehnaz S. (2011). Plant Growth-Promoting Bacteria Associated with Sugarcane. In: Maheshwari D. (eds) Bacteria in Agrobiology: Crop Ecosystems. Springer, Berlin, Heidelberg, 165-187. 
[8] Chaitanya K, Mahmood SK, Ranakausar and Sunil KN. (2014). Polymer producing bacteria showing siderophore activity with chrome azurol S (CAS) agar plate assay. International Journal of Scientific and Research Publications, 4 (12), 1-3.

[9] Tay Ninh Statistics Office. (2017). Tay Ninh Province Statistical Yearbook 2017. Statistical Publishing House, Vietnam.

[10] Trần T. (1999). Sugarcane planting techniques. Agriculture Publishing House, Vietnam.

[11] Nguyen HH, Fani R, Le NT, Nguyen BN, Tran TNT and Pham TK Van. (2008). Isolation of endophytes for the production of biofertilizer at lab scale for the cultivation of sugarcane in Soc Trang province. Can Tho University Journal of Science, 8, 149-157.

[12] Hoang MT and Cao ND. (2014). Characterization and identification of endophytic bacteria Gluconacetobacter diazotrophicus in sugarcane cultivated in Ben Tre and Long An provinces. Journal of Agriculture and Rural Development, 24, 68-74.

[13] Hoang MT and Cao ND. (2014). Isolation, Characterization and Identification of Endophytic Bacteria in Sugarcane (Saccharum spp. L.) Cultivated on Soils of the Dong Nai Province, Southeast of Vietnam. American Journal of Life Sciences, 2(6), 361-368.

[14] Hoang MT and Cao ND. Isolation and Identification of Rhizospheric Bacteria in Sugarcane (Saccharum spp. L.) Cultivated on Acrisols and Ferrasols of Dong Nai Province, the Southeast of Vietnam. American Journal of Life Sciences, 3(2), 109-118.

[15] Nguyên HT, Hoang MT and Cao ND. (2014). Characterization of endophytic bacteria in sugarcane cultivated in Ben Tre and Long An provinces. Journal of Agriculture and Rural Development, 2, 41-48.

[16] Cao ND and Bui TKO. Effect of Pseudomonas spp. on sugarcane yield and sugar concentration in sugarcane (Saccharum officinarum L.)(cv. VĐNL-7) cultivated on acid sulphate soil of Ben Luc district, Long An province. Can Tho University Journal of Science, 6, 69-76.

[17] Cao ND, Nguyen TT, Vo VPQ and Nguyên VA. (2011). Effects of nitrogen-fixing Gluconacetobacter diazotrophicus and phosphatesolubilizing Pseudomonas stutzeri on sugarcane (Saccharum officinalis L.) cultivated on acid sulphate soil of Long An province. Can Tho University Journal of Science, 18b, 29-35.

[18] Suman A, Yadav AN and Verma P. (2016). Endophytic Microbes in Crops: Diversity and Beneficial Impact for Sustainable Agriculture in Microbial Inoculants in Sustainable Agricultural Productivity. Springer India, 1, Research Perspectives, 117-143.

[19] Luster J and Finlay R. (2006). Handbook of Methods Used in Rhizosphere Research. Swiss Federal Research Institute WSL, Birmensdorf, Switzerland.

[20] Parka M, Kim CW, Yang C, Lee H, Shin W, Kim S and Sa T. (2004). Isolation and characterization of diazotrophic growth promoting bacteria from rhizosphere of agricultural crops of Korea. Microbiol. Res, 160(2), 127-133.

[21] Nautiyal CS. (1999). An efficient microbiological growth medium for screening phosphate solubilizing microorganisms. FEMS Microbiol. Lett, 170(1), 265-270.

[22] Garg N, Garg KL and Mukerji KG. (2010). Laboratory Manual of Food Microbiology. I. K. International Pvt Ltd, India.

[23] Graevenitz AV and Buche C. (1983). Accuracy of the KOH and vancomycin tests in determining the Gram reaction of non-enterobacterial rods. J Clin Microbiol, 18(4), 983-985.

[24] Gordon SA and Weber RP. (1951). Colorımetrıc estımatıon of indoleacetıc acıd. Plant Physiol, 26(1), $192-195$.

[25] Ventorino V. (2016). Lignocellulose-Adapted Endo-Cellulase Producing Streptomyces Strains for Bioconversion of Cellulose-Based Materials. Front Microbiol, 7, 1-15.

[26] Solarzano L. (1969). Determination of ammonia in natural waters by the phenolhypochlorite methods. Limnology and Oceanography, 14(5), 799-801.

[27] Murphy J and Riley JP. (1962). A modified single solution method for the determination of phosphate in natural waters. Analytica Chimica Acta, 27, 31-36.

[28] Schwyn B and Neilands JB. Universal chemical assay for the detection and determination of siderophores. Anal. Biochem, 160 (1), 47-56. 
[29] Mew TW and Misra JK. (1994). A Manual of Rice Seed Health Testing. Int. Rice Res. Inst., Philippines.

[30] Arora NK and Verma M. (2017). Modified microplate method for rapid and efficient estimation of siderophore produced by bacteria. Biotech, 7(6), 1-9.

[31] Milagres AM, Machuca A and Napoleão D. (1999). Detection of siderophore production from several fungi and bacteria by a modification of chrome azurol S (CAS) agar plate assay. J. Microbiol. Methods, 7(1), 1-6.

[32] Chaitanya K, Mahmood SK, Ranakausar and Sunilkumar NS. (2014). Polymer producing bacteria showing siderophore activity with chrome azurol S ( CAS ) agar plate assay. International Journal of Scientific and Research Publications, 4(12), 1-3.

[33] Balouiri M, Sadiki M and Ibnsouda SK. (2016). Methods for in vitro evaluating antimicrobial activity: A review. Journal of Pharmaceutical Analysis, 6(2), 71-79.

[34] Hastuti RD, Lestari Y, Suwanto A and Saraswati R. (2012). Endophytic Streptomyces spp. as Biocontrol Agents of Rice Bacterial Leaf Blight Pathogen (Xanthomonas oryzae pv. oryzae). HAYATI Journal of Biosciences, 19 (4),155162.

[35] Shrivastava G, Kuma K and Yandigeri M. (2017). In vitro biocontrol activity of halotolerant Streptomyces aureofaciens K20: A potent antagonist against Macrophomina phaseolina (Tassi). Saudi Journal of Biological Sciences, 24, 192-199.

[36] Kumar S, Stecher G, Li M, Knyaz C and Tamura K. "MEGA X: Molecular Evolutionary Genetics Analysis across Computing Platforms. Mol. Biol. Evol, 35 (6), 1547-1549.

[37] Baldani JI, Reis VM, Videira SS, Boddey LH and Baldani VLD. (2014). The art of isolating nitrogen-fixing bacteria from non-leguminous plants using N-free semi-solid media: a practical guide for microbiologists. Plant Soil, 384 (1), 413-431.

[38] Dang TNT, Nguyen TXM and Cao ND. (2016). Indole acetic acid and siderophore production by selected isolates of plant associated bacteria and their effects on growth of maize (Zea mays L.) in pot experiments. Can Tho University Journal of Science, 47, 59-67.

[39] Hoang MT, Dang TNT and Thai LNBT. (2019). Isolation and Characterization of Actinobacteria in Rhizosphere of Crinum latifolium (L.) Cultivated in Tay Ninh Province, Vietnam. International Journal of Innovations in Engineering and Technology, 13(4), 026-033.

[40] Dang TNT and Do TT. (2018). Isolation and Characterization of Plant Growth Promoting Rhizobacteria in Black Pepper ( Piper nigrum L .) Cultivated in Chon Thanh and LocNinh Districts of BinhPhuoc Province, Vietnam. International Journal of Innovations in Engineering and Technology (IJIET), 10(1), 01-010.

[41] Nielsen A, Mansson M, Wietz M, Varming NA, Phipps KR, Larsen TO, Gram L and Ingmer H. (2012). Nigribactin, a novel siderophore from Vibrio nigripulchritudo, modulates Staphylococcus aureus virulence gene expression. Mar Drugs, 10(11), 2584-2595.

[42] Xu S, Wang J, Wang H, Bao Y, Li Y, Govindaraju M, Yao W, Chen B and Zhang M. (2019). Molecular characterization of carbendazim resistance of Fusarium species complex that causes sugarcane pokkah boeng disease. BMC Genomics, 20(1), 115.

[43] Girish K and Sushma G. (2018). Screening of bacteria for antifungal activity against phytopathogenic fungi of sugarcane (Saccharum officinarum L.). EurAsian Journal of BioSciences, 12, 195-203.

[44] Sivasakthi S, Usharani G and Saranraj P. (2014). Biocontrol potentiality of plant growth promoting bacteria (PGPR) - Pseudomonas fluorescens and Bacillus subtilis: A review. Afr. J. Agric. Res., 9(16), 1265-1277.

[45] Antwerpen TV, Rutherford R and Vogel J. (2001). Assessment of sugarcane endophytic bacteria and rhizospheric Burkholderia species as antifungal agents. Proc Annu Congr S Afr Sugar Technol Assoc, 76, 301-304.

[46] Rooney AP, Dunlap CA and Flor-Weiler LB. (2016). Acinetobacter lactucae sp. nov., isolated from iceberg lettuce (Asteraceae: Lactuca sativa). Int. J. Syst. Evol. Microbiol, 66(9), 3566-3572.

[47] Zhang CW, Zhang J, Zhao JJ, Zhao X, Zhao DF, Yin HQ and Zhang XX. (2017). Serratia oryzae sp. nov., isolated from rice stems. Int. J. Syst. Evol. Microbiol, 67(8), 2928-2933.

[48] Radhakrishnan R, Hashem A and Allah EFA. (2017). Bacillus: A Biological Tool for Crop Improvement through Bio-Molecular Changes in Adverse Environments. Front Physiol, 8, 667. 
[49] Borriss R. (2011). Use of Plant-Associated Bacillus Strains as Biofertilizers and Biocontrol Agents in Agriculture. Springer, in Bacteria in Agrobiology: Plant Growth Responses, 41-76.

[50] Hashem A, Tabassum B and Allah EFA. (2019). Bacillus subtilis: A plant-growth promoting rhizobacterium that also impacts biotic stress. Saudi Journal of Biological Sciences, 26 (6), 1291-1297.

\section{How to cite this article}

Hoang MT, Dang Thi NT and Cao ND. (2020). Functional and molecular characterization of plant growth promoting bacteria associated with sugarcane cultivated in Tay Ninh Province, Vietnam. GSC Biological and Pharmaceutical Sciences, 3(2), 265-277. 